\title{
Intersubjectivity and the Sociology of Alfred Schutz
}

\author{
By JOAQUIN TRUJILLO
}

\begin{abstract}
This article endeavors to answer three questions. (1) What is the interpretation of intersubjectivity posited by the sociology of Alfred Schutz? (2) Can we augment it by way of Husserl's transcendental-phenomenological investigation of intersubjectivity? (3) What can Heidegger's hermeneutics of intersubjectivity add to Schutz's interpretation? The answer to the first question comprises six theses wrested from Schutz's sociology. The analysis responds negatively to the second question. Its answer to the third question suggests the exposure of Schutz's interpretation of intersubjectivity to Heidegger's hermeneutics extends its exhibition of the phenomenon, enhances the disclosing-saying power of his sociology, and primes its empirical development.
\end{abstract}

Keywords Alfred Schutz, intersubjectivity, sociology, phenomenology, hermeneutics.

This article responds to three questions. (1) What is the interpretation of intersubjectivity posited by the sociology of Alfred Schutz? (2) Can we augment it by way of Husserl's transcendental-phenomenological investigation of intersubjectivity? (3) What can Heidegger's hermeneutics of intersubjectivity add to Schutz's interpretation?

\section{Alfred Schutz (1899-1959)}

Alfred Schutz was born in Austria in 1899. He graduated the University of Vienna with a degree in law. There he also studied economy and sociology, 
including the interpretive sociology of Max Weber. He later applied Husserl's phenomenology to clarify ambiguities he identified in Weber's rendition of subjective meaning and social action. He came to Husserl's attention in 1932 shortly after the publication of The Phenomenology of the Social World (Der sinnhafte Aufbau der sozialen Welt), which he had dedicated to Husserl. H.R. Wagner says the manuscript "merited the subtitle, 'Husserl and Weber", because their writings were "the cornerstones" of Schutz's sociology, which also absorbed theses from Henri Bergson, William James, and Max Scheler ${ }^{1}$. Schutz emigrated to the U.S. in 1939 to escape the rise of Fascism and Nazism in Europe, and died in New York in 1959. He spent most of his career working as a banker, taught part-time at the Graduate Faculty of the New School of Social Research, and became a fulltime professor there in 1952. His colleagues included Aron Gurwitsch, Karl Löwith, Dorion Cairns, Carl Mayer, and Albert Salomon². Schutz was a founding member of the International Phenomenological Society and a founding editor of the journal, Philosophy and Phenomenological Research. His articles, more than 30 , were frequently published there as well as in Social Research, American Journal of Sociology, Review of Metaphysics, Economica, and Journal of Philosophy. These works, and others, are included in Collected Papers I-III ${ }^{3}$. Although Schutz authored only one book during his life, his comprehensive outlines and notes for planned works were posthumously edited and published as two separate studies: Reflections of the Problem of Relevance $e^{4}$ and The Structures of the Life-World (two volumes) ${ }^{5}$, the second of which was completed by his former student, Thomas Luckmann.

\footnotetext{
${ }^{1}$ Helmut R. Wagner, "Introduction", in On Phenomenology and Social Relations: Selected Writings, ed. Helmut R. Wagner (Chicago: University of Chicago Press, 1970), p. 1.

2 Thomas Luckmann, "Preface", in The Structures of the Life-World, vol. 1 (Evanston: Northwestern University Press, 1973), p. xviii.

${ }^{3}$ Alfred Schutz, Collected Papers I: The Problem of Social Reality, ed. I. Schutz (The Hague: Martinus Nijhoff, 1972); Collected Papers II: Studies in Social Theory (The Hague: Martinus Nijhoff, 1976); Collected Papers III: Studies in Phenomenological Philosophy (The Hague: Martinus Nijhoff, 1966).

4 Reflections on the Problem of Relevance (New Haven: Yale University Press, 1970).

5 Alfred Schutz and Thomas Luckmann, The Structures of the Life-World, trans. Richard M. Zaner and Jr. H. Tristram Engelhardt, vol. 1 (Evanston: Northwestern University Press, 1973); ibid., 2.
} 
In his introduction to The Phenomenology of the Social World, G. Walsh writes, "by applying Husserl's concept of meaning to social action", which Schutz designates as "human conduct" and renders as "an ongoing process which is devised by the actor in advance", "is based upon a preconceived project", and may occur "by commission or omission"1, he [Schutz] "was able to recast the foundations of interpretive sociology" and put it on a phenomenological basis ${ }^{2}$. True. Schutz defensibly argued phenomenology's inclusion in the social sciences, used the method to elucidate basic theses of Weber's interpretive sociology, and developed a robust framework to examine social phenomena. Husserl's observations about Schutz's research underscore his phenomenological acumen. In 1932, he wrote to Schutz: "I I am anxious to meet such a serious and thorough phenomenologist, one of the few who have penetrated to the core of the meaning of my life's work"'3. The compliment was merited. Schutz demonstrated an irrefutable command of Husserl's phenomenology, as witnessed, for example, in his articles, "Some Leading Concepts in Phenomenology", "Discussion: Edmund Husserl's Ideas, Volume II" "Type and Eidos in Husserl's Late Philosophy"6, "The Problem of Transcendental Intersubjectivity in Husserl"7, and other writings. Schutz's careful, insightful readings of the works of Merleau-Ponty, for example, in "Language, Language Disturbances, and the Texture of Consciousness" ${ }^{8}$, and Max Scheler ${ }^{9}$ further demonstrate his phenomenological acumen.

1 Alfred Schutz, "Choosing Aamong Projects of Action", Philosophy and Phenomenological Research 12, no. 2 (1951), p. 161.

2 George Walsh, "Introduction", in The Phenomenology of the Social World (Evanston: Northwest University Press, 1967), p. xvii.

${ }^{3}$ Ibid., p. xviii.

${ }^{4}$ Alfred Schutz, "Some Leading Concepts of Phenomenology", Social Research 12, no. 1 (1944).

5 “Discussion: Edmund Husserl's Ideas, Volume II", Philosophy and Phenomenological Research 13, no. 3 (1953).

6 "Type and Eidos in Husserl's Late Philosophy", in Collected Papers III: Studies in Phenomenological Philosophy, ed. I. Schutz (The Hague: Martinus Nijhoff, 1966).

7 "The Problem of Transcendental Intersubjectivity in Husserl", in Collected Papers

III: Studies in Phenomenological Philosophy, ed. I. Schutz (The Hague: Martinus Nijhoff, 1966).

8 "Language, Language Disturbances, and the Texture of Consciousness", Social Research 17, no. 3 (1950).

9 "Scheler's Theory of Intersubjectivity and the General Thesis of the Alter Ego", Philosophy and Phenomenological Research 2, no. 3 (1942); "Max Scheler's Epistemology and Ethics, I", The Review of Metaphysics 11, no. 2 (1957); "Max 


\section{The life-world of the natural attitude}

Gurwitsch writes that Schutz "deliberately abstains from raising questions of transcendental constitution" and contains his phenomenological analyses within the "framework of Husserl's discernment of the "natural attitude"" . Yes. His phenomenology signifies a discovery of the life-world of the natural attitude, or the "world of daily life". This world, as Schutz discerns it, is the "self-evident", "pre-scientific", and "taken-for-granted" world and our "fundamental and paramount reality". It is the world of immediate experience ${ }^{3}$, the "public" world and the world "common to all of us"4; it is "not the private world of the single individual" . The life-world of the natural attitude is the "reality" of the everyday person on the street, or the "wide-awake", "grown-up" person living life among his fellow persons taking the world they live and share as it is given to them ${ }^{6}$; "wide-awakeness" denotes a mode of awareness "of the highest tension originating in an attitude of full attention to life and its requirements"

The world of daily life is the world dominated by "eminently practical" interests, the correlate of "wide-awakeness", rather than "theoretical" ones $^{8}$. It is the world we must change to realize the purposes we pursue within it among our fellow-persons, and the world we naturally operate "within" and "upon"9. It is an ordered world, but not "homogenous". It is largely "incoherent", "only partially clear", and "not at all free from contradictions" $"$. It is typically structured, typically understood, and typically enacted upon, "a reality that is fundamentally and typically familiar" ${ }^{11}$. The

Scheler's Epistemology and Ethics: II", The Review of Metaphysics 11, no. 3 (1958); "Scheler's Criticism of Kant's Philosophy".

${ }^{1}$ Aron Gurwitsch, "Introduction", ibid., pp. xiv-xv.

${ }^{2}$ Schutz and Luckmann, The Structures of the Life-World, 1, p. 3.

${ }^{3}$ Gurwitsch, "Introduction", pp. xi-xiii.

4 Ibid.; Alfred Schutz, "Common-Sense and Scientific Interpretation of Human Action", Philosophy and Phenomenological Research 14, no. 1 (1953).

5 “On Multiple Realities", Philosophy and Phenomenological Research 5, no. 4 (1945), p. 534.

${ }^{6}$ Ibid., p. 533.

${ }^{7}$ Ibid., p. 538 .

${ }^{8}$ Ibid., p. 534.

9 "The Stranger: An Essay in Social Psychology", American Journal of Sociology 49, no. 6 (1944), pp. 499-500; “On Multiple Realities”, p. 534.

10 "The Stranger: An Essay in Social Psychology", p. 500.

${ }^{11}$ Schutz and Luckmann, The Structures of the Life-World, 1, p. 7. 
everyday person laboring in/with/upon the life-world of the natural attitude is only partially interested "in the clarity of his knowledge". His pursuit of knowledge is largely driven by motivations to obtain "information on likelihood and insight into the chances or risks which the situation at hand entails for the outcome of his actions"'.

The purposes of the actions of the everyday person, the meaning of those (social) actions, are largely drawn from an inventory of learned, biographically informed, socially oriented, taken-for-granted typifications ${ }^{2}$. Schutz calls this inventory a person's "stock of knowledge at hand". The stock of knowledge at hand signifies the comprehension and architecture of the life-world of the natural attitude. It harbors intentionally structured meanings endemic to the management and execution of daily living. It is a matrix of typical meanings (typifications) through which the human person "automatically" comprehends and lives the world among his fellow persons ${ }^{3}$. Typifications are not necessarily precise, scientific, logical, or consistent, although they are, as the meaning of actions usually go, rational, meaning they comprise means-ends relations, which Schutz differentiates as either "in-order-to" and "because" motives ${ }^{4}$. Typifications are general, openended meanings. They are taken-for-granted "pre-experiences", or "a sort of preknowledge", that denote "open horizons of anticipated similar experiences" and usually go "unquestioned" as long as they accomplish their implicit purposes 5 . They are comprehended, transmitted, and ordered communicatively through language. They are contained in language.

According to Schutz, the concerns of the everyday person in the natural attitude are dominated by spatially and temporally structured pragmatic motivations ("means-and-ends relations"6) ensuing from a biographically and culturally determined past laying itself out (sedimenting) "in time" toward a projected, individually unique, intersubjectively shaped future ${ }^{7}$. The future of the everyday person largely comprises typically defined and engendered projects he seeks to fulfill that pertain to his spheres

${ }^{1}$ Schutz, "The Stranger: An Essay in Social Psychology", p. 501.

2 "The Problem of Rationality in the Social World", Economica 10, no. 38 (1943), p. 137.

${ }^{3}$ Ibid., p. 136.

4 "On Multiple Realities".

5 "Common-Sense and Scientific Interpretation of Human Action", p. 5; "Making Music Together: A Study in Social Relationship", Social Research 18, no. 1 (1951), p. 85.

6 "The Stranger: An Essay in Social Psychology", p. 500.

7 “On Multiple Realities", pp. 538-542. 
of relevance, or horizons of noetic-noematic significance distinguished by gradations of "manifold forms of intimacy and anonymity" that one way or another and to different degrees always belong to the "cultural pattern of group life". . One's spheres ("zones") of relevance begin with the "sector of the world" wherein one is immediately situated and extend to situations that at any given time are within one's spatial-temporal "scope" or "reach", including "adjacent ones" of "potential working", to zones of only referential significance ${ }^{2}$.

\section{Schutz's hermeneutics of intersubjectivity}

Schutz purposefully shelves questions of transcendental constitution Husserl posits and strives to answer in his investigation of intersubjectivity. $\mathrm{He}$ "abandons the strictly phenomenological method" Husserl employs and circumvents the "nest of [phenomenological] problems" he assesses it surfaces (e.g., whether or how "the Thou is constituted in an Ego"3). Instead, he delivers a "pragmatic interpretation" of "cognitive life" 4 that renders intersubjectivity within the "mundane sphere" of the life-world". His rendition of the phenomenon can be distilled into six basic theses.

1. Subjectivity is intersubjectivity. Intersubjectivity is originary to the life-world. It permeates the "vivid present"". The life-world of the natural attitude "is intersubjective from the very beginning" . Its "fundamental

1 "Common-Sense and Scientific Interpretation of Human Action", p. 11; "The Problem of Rationality in the Social World", pp. 135-136; "The Well-Informed Citizen: An Essay on the Social Distribution of Knowledge", Social Research, 13, no. 4 (1946), p. 468; Schutz, "The Stranger: An Essay in Social Psychology", p. 499. 2 "On Multiple Realities", pp. 540-547; "Common-Sense and Scientific Interpretation of Human Action", p. 11.

3 The Phenomenology of the Social World, trans. George Walsh and Frederick Lehnert (Evanston: Northwest University Press, 1967), pp. 97-98; Schutz and Luckmann, The Structures of the Life-World, 1, p. 3; David Carr, "Introduction", in The Crisis of European Sciences and Transcendental Phenomenology: An Introduction to Phenomenological Philosophy (Evanston: Northwestern University Press, 1970), pp. xli-xlii.

${ }^{4}$ Schutz, "On Multiple Realities", p. 538.

5 "Scheler's Theory of Intersubjectivity and the General Thesis of the Alter Ego", p. 337.

${ }^{6}$ Ibid., p. 343.

${ }^{7}$ Schutz and Luckmann, The Structures of the Life-World, 1, p. 15.

6

Bull. anal. phén. XIV 7 (2018)

https://popups.uliege.be/1782-2041/ (c) 2018 ULiège BAP 
structure" is intersubjective ${ }^{1}$. "World-experience" is not "private experience". It is "shared experience". The world of daily life is "the "world for all of us", not withstanding it is also "primarily "my" world"2. The intersubjectivity of the life-world is the "precommunicative" basis upon which all social relationships as well as the "mutual tuning-in" relations Schutz says precedes the meaningful "We", or the togetherness of the "I" and "Thou" in "vivid presence", are founded 3 .

2. Intersubjectivity is a potentiality. Schutz means this in two ways. First, intrinsic to presence, vivid or otherwise and in all of its gradations of intimacy, is "the possibility of living together simultaneously in specific dimensions of [space and] time"4. Second, the disposition of the wide-awake person includes the possibility, impulse, and power to develop the comprehension of the life-world he shares with others. The everyday person is continuously growing and refining his stock of knowledge; "every empirical idea of the general has the character of an open concept to be rectified or corroborated by supervening experience" 5 . The stock of knowledge at hand, as Gurwitsch notes, is intrinsically incomplete and "enlarges" in the person as his "life goes on".

3. Intersubjectivity is learned. Only a fraction of one's stock of knowledge at hand originates from personal experience. "The bulk of it is socially derived, handed down to me and accepted by me" as "the frame of reference, interpretation, and orientation for my life in the world of daily experience" ". It is largely produced through/within/from group living. It is an assimilation of the experiences of others.

4. Intersubjectivity is typical. The typical meanings that constitute the stock of knowledge are common meanings. They are shared. They are "typical means for bringing about typical ends in typical situations". They belong to everyone and no one. "The factual world of our experience", the world one fundamentally shares with others and the paramount reality as such, "is experienced from the outset as a typical one"".

\footnotetext{
${ }^{1}$ Ibid., p. 3.

${ }^{2}$ Schutz, "The Problem of Transcendental Intersubjectivity in Husserl", p. 54.

3 "Making Music Together: A Study in Social Relationship", p. 79.

${ }^{4}$ Ibid.

5 "Language, Language Disturbances, and the Texture of Consciousness", p. 389.

${ }^{6}$ Gurwitsch, "Introduction", p. xvii.

${ }^{7}$ Ibid., pp. xvii-Xviii.

${ }^{8}$ Schutz, "Common-Sense and Scientific Interpretation of Human Action", p. 10.

9 "Language, Language Disturbances, and the Texture of Consciousness", p. 388.
} 
5. Intersubjectivity is pragmatic. The life-world of the natural attitude is grounded in the concreteness of human living. It is immanently connected to the dependence of the person on things and persons to live and be; "it is our interest at hand that motivates all our thinking, acting, and therewith establishes the problems to be solved by our thoughts and the goals to be attained by our actions"1. The proposition, "intersubjectivity is pragmatic", denotes the coupling of intersubjectivity to the exigencies of daily living, or the "practical" tasks before us ${ }^{2}$.

6. Intersubjectivity is language. Language is the wheelhouse of socially derived knowledge and "the typifying medium par excellence" by which the shared comprehension of the world is "transmitted" 3 . It contains the typifications the everyday person employs to comprehend and navigate everyday life. "Language presupposes typification", and subjectivity is typically shared through language ${ }^{4}$. Language belongs "to the intersubjective world of working". It embodies the world of daily life and defines the realms "relevant" to a person ${ }^{5}$. It is the intersubjective "means for realizing one's own acts and thoughts", "the paramount vehicle of communication", "the outstanding tool for the conveying of meaning", and, for the most part, "nonconceptual"? The world of daily life, the reality everyday persons endure in his their wide-awakeness, is interpretively shared (and lived) through language.

\section{Husserl's hermeneutics of intersubjectivity}

Schutz calls the fifth of Cartesian Meditations ("Fifth Meditation") Husserl's most rigorous study of intersubjectivity. Is there more to be gleaned from that document that could contribute to Schutz's discernment of the phenomenon? Schutz's analysis of Husserl's investigation of intersubjectivity, the one he provides in his article, "The Problem of Intersubjectivity in Husserl", to determine whether the "results of phenomenological constitutional analysis

1 "The Well-Informed Citizen: An Essay on the Social Distribution of Knowledge", p. 467.

2 Schutz, "Language, Language Disturbances, and the Texture of Consciousness", pp. 391-392.

3 "Common-Sense and Scientific Interpretation of Human Action", p. 10.

${ }^{4}$ Schutz and Luckmann, The Structures of the Life-World, 1, p. 233.

${ }^{5}$ Schutz, "On Multiple Realities", pp. 537, 555.

6 "The Stranger: An Essay in Social Psychology", p. 504.

7 “Making Music Together: A Study of Social Relationship", pp. 77-78 
are applicable to all social sciences", says, "no". He repeats this assessment in "Scheler's Theory of Intersubjectivity and the General Thesis of the Alter Ego", where he locates intersubjectivity - the "experience of the other's stream of consciousness"-in "vivid simultaneity", or the present that is "common to both of us" and "the pure sphere of the "We"". Schutz's exhaustive analysis of Husserl's project delivers the conclusion that he (Husserl) did not satisfactorily explain how the "transcendental ego can constitute in itself another transcendental ego" or "constitute an open plurality of such egos"3. Many students of the phenomenological movement might agree with Schutz's assertion. The overarching goal of this article, to extend our understanding of intersubjectivity as such, compels a review of the principal theses Husserl posits in his treatise. Also, an appreciation of Husserl's thinking gives way to a clearer understanding of Heidegger's hermeneutics of intersubjectivity, this paper surmises.

In "Fifth Mediation", Husserl posits the question of intersubjectivity as follows:

We must, after all, obtain for ourselves insight into the explicit and implicit intentionality wherein the alter ego becomes evinced and verified in the realm of our transcendental ego; we must discover in what intentionalities, syntheses, motivations, the syntheses, motivations, the sense "other ego" becomes fashioned in me and, under the title, harmonious experience of someone else, becomes verified as existing and even as itself there in its own manner ${ }^{4}$.

Husserl delivers a two-part response to the problematic he poses. Both parts source intersubjectivity to intentional constitution. He claims to "apodic-

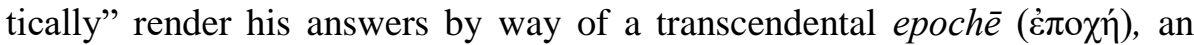
effected mode of knowing he says thematically withholds assent of everything within intentionality ("total world-phenomenon") except the significations he imputes exclusively to the Ego (transcendental ego), or the noetic "pole" of consciousness. He calls these significations "Egodeterminations", the Ego's "spiritual ownness", and the "ultimate" or "ab-

1 "The Problem of Transcendental Intersubjectivity in Husserl", p. 55.

2 "Scheler's Theory of Intersubjectivity and the General Thesis of the Alter Ego", pp. 336, 343.

3 "The Problem of Transcendental Intersubjectivity in Husserl”, pp. 54, 82.

${ }^{4}$ Edmund Husserl, "Fifth Meditation", in Cartesian Mediations: An Introduction to Phenomenology (Boston: Kluwer Academic Publishers, 1999), p. 90. 


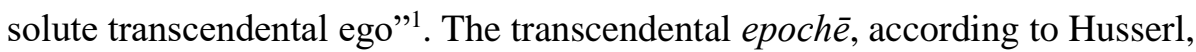
is a manner of awareness produced from a decision to disregard "all constitutional effects of intentionality relating immediately or mediately to other subjectivity ["others"]" and delimits the total actual and potential intentionalities wherein the Ego constitutes its ownmost significance. In this epoche, the knowing ego knows (abides, dwells in, yields itself to) only its "transcendental sphere of peculiar" or "exclusive ownness", that which Husserl says is "purely in myself and for myself", the "transcendental concrete I-myself". The "other", revealed by the general reduction of the natural attitude as its own, unique transcending, as a human person existing in the world, is not known in the "transcendental attitude", according to Husserl $^{2}$. Only the Ego (the "primordial world" and "primordial transcendence") and its primal characteristics are intuited ${ }^{3}$. The "other", as Husserl renders it, is not ingredient to the Ego. It does not come originarily with the nucleation of intentionality and the manifestation (emergence) of consciousness.

1. Analogous Constitution. According to Husserl, the Ego, the nucleus of subjectivity, constitutes the "other" analogously and associatively; the first process, he says, is the more primitive one. Analogous constitution signifies a "passive synthesis of "identification" "' that correlates the animate body of the "other" with the phenomenal body of the "self", the known or intentional constituted body, and imputes it a consciousness; the Ego-body, the body of the concrete I, belongs to the transcendental ego. The transcendental ego initially comes to know the "other" as an "alter ego" it ascribes its intentional constitution of the "Objective" world, or "Nature" (world-phenomenon) 5 The alter ego is a noetic construct. It is constituted in the Ego. It is a sort of "'mirroring"" of one's "own self" in one's "own Ego", in one's "monad"6. The transcendental ego passively projects its "self" on the referent (noematically signified) animate body and automatically posits the certainty the body has its own Ego. It assumes the body of the "other" is not an automaton, not a mere animal, or living thing devoid of human transcendence, but instead noetically intends (constitutes) it as a living and knowing human person in and for itself. The alter ego "is not simply there and strictly

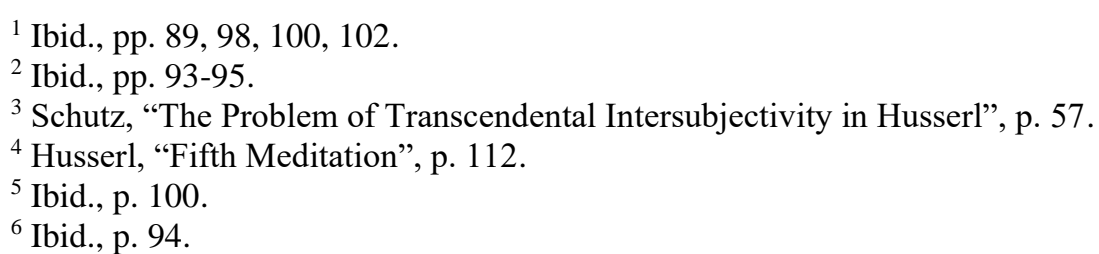


presented"1. It is imputed its own transcending. The alter ego, the ego originarily "appresented" (constituted) other than mine by the (absolute) transcendental ego, is, according to Husserl: "I myself, constituted within my primordial ownness, and uniquely, as the psychophysical unity (the primordial man)". It is a reflection of the " personal' Ego, the intentional processes "governing immediately in my animate organism". The alter ego is produced by way of "“analogizing" apprehension"2. Its meaning echoes the primitive significance of "my" body, the only real body found in the transcendental epoche, according to Husserl, and "my" consciousness "producing effects mediately in the primordial surrounding world" and "functionally joined in a single perception that is at once presenting and appresenting"4.

2. Associative Constitution. The second way the transcendental ego constitutes the "other", albeit, at a "higher level" of intentionality, according to Husserl ${ }^{5}$, although he indicates nothing to suggest it does not happen simultaneously, is by passively associating its knowing of the world (and others) with the alter ego it imputes to others, a phenomenon he also calls, "pairing". Through passive association, "pairing", the Ego involuntarily ascribes its prereflective awareness of the world to the alter ego. It spontaneously assumes the alter ego intuits the same world it itself intuits and knows the world, or at least contains the possibility of intuiting and knowing it, along the same fundamental lines it knows and can know it. It imputes its baseline comprehension of and openness to the world, including its appropriation of space and time, to the alter ego. Pairing signifies an intentionally constituted "unity of similarity" between the Ego and alter ego. "If there are more than two such data", that is, more than two Egos in play, intending each other, "then a phenomenally unitary group, a plurality, becomes constituted"

These intentional constituting processes, passive identification and passive association, according to Husserl, at least insofar as he surmises them in "Fifth Meditation", are the basis of the common "Objective" world (the life-world) and intersubjectivity as such. They signify a "connection mediated by presentation". They, unfolding "in a synthetically harmonious

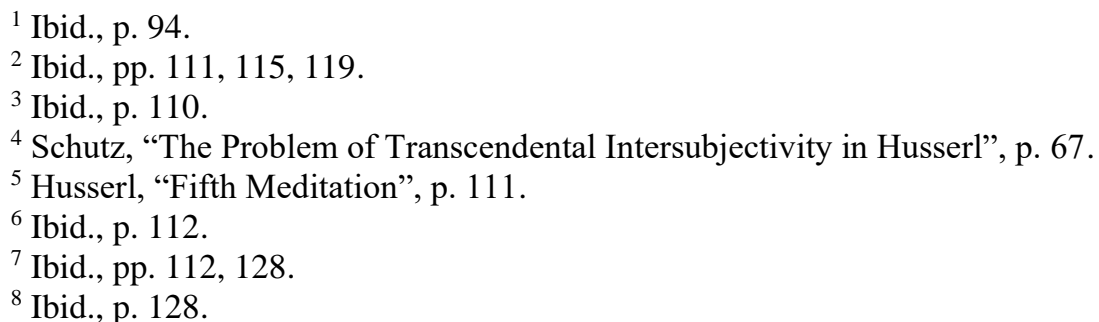


fashion" among distinct and separate monads engender the possibility of "the experienced animate organism of another", an "alien sphere presented" in consciousness, to continually "prove itself" within the "primordial sphere", the transcendental ego, as its own conscious "self". These processes are, as Husserl describes them, the "first and lowest level of communalization between me, the primordial monad for myself, and the monad constituted in me, yet as other and accordingly as existing for himself but only appresentationally demonstrated to me". Their rendition reveals how:

the coexistence of my [polar] Ego and the other Ego, of my whole concrete ego and his, my intentional life and his, my "realities" and his - in short, a common time-form - is primarily instituted; and thus every primordial temporality automatically acquires the significance of being merely an original mode of appearance of Objective temporality to a particular subject. In this connection we see that the temporal community of the constitutively interrelated monads is indissoluble because it is tied up essentially with the constitution of $a$ world and $a$ world time ${ }^{2}$.

It is not difficult to see the thinking of "Fifth Meditation" operating positively and negatively within Schutz's hermeneutics. The correspondences between typification and passive association are perhaps the most explicit positive correlation between their renditions of intersubjectivity. Typifications are passive associations operating in the natural attitude of the life-world and the consciousness of the wide-awake person encountering others (and himself) in everyday life. Schutz augments Husserl's thesis by elucidating their social dimensions, locating them within a common stock of knowledge, and discerning their role shaping the world of daily life. $\mathrm{He}$ compensates for, as he remarks, Husserl's "regrettable ignorance" of the social sciences and his introduction of "unexamined constructs of everyday thinking and of the social sciences into phenomenological analyses of constitution"3. Although Husserl's thought experiment is worthy of further phenomenological and psychological investigation concerning the genesis of typifications in consciousness and their fundamental relation to intentionality-Gurwitsch, for example, calls typifications the "the origin of conceptual consciousness" and "conceptualization in an incipient or at least germinal

\footnotetext{
${ }^{1}$ Ibid., pp. 114, 128.

2 Ibid., p. 128.

${ }^{3}$ Schutz, "The Problem of Transcendental Intersubjectivity in Husserl”, p. 73.
} 
form" - - there is not much more its individuation of passive association can substantially add to Schutz's sociological enterprise, this paper assesses.

"Fifth Mediation" operates negatively in Schutz's thinking insofar as it appears to have induced him to embrace the conclusions Husserl implies in his later investigation of the "life-world", the one he conducts in The Crisis ${ }^{2}$, that transcendence is factically intersubjective and intersubjectivity is not constituted, it is not a synthesis, but is inherent to world-phenomenon. Considerations of the transcendental constitution of an "alter ego", as rendered in Husserl's analysis, hence, are largely absent from Schutz's sociology, except to denote the epistemological reasons for confining his interpretation of intersubjectivity to "the mundane sphere of the life-world"3. Schutz even goes so far as to challenge the validity of Husserl's attempt to reduce intersubjectivity to transcendental constitution: "The transcendentally reduced conscious life, the phenomenon 'world' [World], including the Other, is not experienced as my private synthetic product", he writes in his assessment of Husserl's project, "but as an intersubjective world whose objects are accessible to everyone" 4 .

The purpose of these remarks is not to discredit Husserl's attempt to locate the source of intersubjectivity and the "Objective world" ("Nature and the whole world"') in immanent constitution by way of a "transcendentally reduced ego" ". They also do not censure Husserl for apparently failing to excavate the phenomenological gold connoted by his later discernment of the "life-world", the "prescientifically" self-evident (factically given) "concrete unity" of "that", t/here (the "all-encompassing") and "the one world of experience, common to all"6. Why Husserl withheld yielding to the phenomenological implications of his analysis, that there is one life-world and the "other" is factically given with it, is a mystery. Maybe it was his granite resolve to finish his scientific expedition, the significant investigative possibilities his phenomenological discovery surfaced, or his motivation to discover an "absolute" foundation for the sciences that dissuaded him. Or maybe his thinking fell under the seemingly objectifying sway implicit to the

\footnotetext{
${ }^{1}$ Aron Gurwitsch, "Introduction", ibid., p. xiv.

2 Edmund Husserl, The Crisis of European Sciences and Transcendental Phenomenology: An Introduction to Phenomenological Philosophy, trans. David Carr (Evanston: Northwestern University Press, 1970).

${ }^{3}$ Schutz, "Scheler's Theory of Intersubjectivity and the General Thesis of the Alter Ego", p. 337.

4 “The Problem of Transcendental Intersubjectivity in Husserl”, p. 58.

${ }^{5}$ Husserl, "Fifth Meditation", pp. 89-90.

${ }^{6}$ Ibid., pp. 126, 130, 146-147.
} 
language of his analysis. Husserl's Cartesian thesaurus, no matter how powerful his commitment to scientific rigor and the phenomenological method, implies an objectification of human phenomena and the World. Terms like "constituted", "synthesis", "Objective world", "Ego" and "alter Ego", "monad" ("concrete ego"), "monads", and "monadology", and noesis

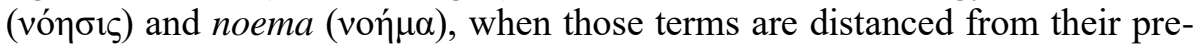
Socratic (pre-philosophical) significance, tend to steer thinking into a course that objectifies human reality ( $\varphi$ aıvó $\mu \varepsilon v o v)$. The phenomenological seeing Husserl denotes by his transcendental epoche, the effort he says delivers the thinker to one's "concrete being as a monad, purely in myself and for myself with an exclusive ownness"1, constituting the world and "others" resonates with a sense of phenomenological voyeurism and compels one to question the method's final relation to thinking as such. Husserl may have indeed had the power to reduce utterly the world, eidetically, transcendentally, or otherwise, and arrive at the "sphere of original self-explication", an "original sphere" where one comes to a "pure" transcendent or intentional world accruing "on the basis of intentional phenomenon", but his assertion the "'Objective,' which belongs to everything worldly-as constituted intersubjectively, as experienceable by everyone, and so forth-vanishes completely"3, is tough to swallow for us mere mortals. The ultimate value of the epoche, transcendental or otherwise, may be its power to incite thinking as such (inceptual thinking) to enter the course of projecting-opening (Entwerfen) phenomena, inabiding (inständig) them, and caring for, listening and attuning to, and freeing the meaning of human being, intentionality, and "to be" to shine forth and show themselves from themselves as they are as opposed to distilling them reflectively into a posited system of basic elements. The fact that space and time (entropy), the "spatiotemporal form", as Husserl indicates, endure within the reduction testifies to the inherent limitations of the transcendental epochē. The World, "others", and the "self", beginning with the phenomenal body, as Merleau-Ponty scrupulously denotes in his analysis of subjectivity and the life-world, belong to space and time $^{4}$. Persons and things coalesce within space and time into a unity that

\footnotetext{
${ }^{1}$ Ibid., p. 92.

${ }^{2}$ Ibid., pp. 105, 144.

${ }^{3}$ Ibid., p. 96.

4 Maurice Merleau-Ponty, Phenomenology of Perception, trans. Colin Smith (London: Routledge \& Kegan Paul, 1962), p. 141.
} 
does not vanish through purposeful reflection into "reduced worldphenomenon".

Husserl's investigation of intersubjectivity, despite its apparent shortcomings, does not detract from its scientific value. His formidable analysis is pregnant with possibilities that beckon phenomenological (empirical) discovery. Perhaps one of its more lasting contributions is the extent to which it reveals intentional constitution can affect the comprehension of the life-world, The exclusive ownness of primordial intentional constitution, as witnessed in the experiences of the neurotic, depressed, and schizophrenic, can significantly alter the way the human person experiences the world and encounters "others". The constituting processes Husserl unearthed in his transcendental-phenomenology of intersubjectivity suggest intentional constitution, no matter how tiny its influence may be, can significantly alter World-meaning. The transcendental ego may not generate the "other", the "transcendental "We", or the "Objective world" through a harmonious "communalization of constitutive intentionality" with other transcendental egos, as Husserl posits ${ }^{2}$, but it can indeed darken, distort, disclose, and illuminate human phenomena, as well as create the conditions that invite meaningfulness to ensue in human living or abandon it to meaninglessness.

Schutz's genius is evidenced in his command of Husserl's transcendental-phenomenology, appropriation of basic aspects of intersubjectivity it illuminated, and progress traversing the course of thinking Husserl lays out in his analysis of the life-world and elucidating its social dimensions. Schutz executes the leap Husserl declined and arrived at the phenomenological (propositional) conclusion that "intersubjectivity is not a problem of constitution which can be solved in the transcendental sphere but is rather a datum (Gegebenheit) of the life-world"3. The "other" ("intersubjectivity", the "we-relationship") is (ontologically) intrinsic to human being ("human existence in the world"). It categorically belongs to everything persons are and do, to all their actualities and possibilities. It frees thinking (including that of being, ultimate meaning, and reality), projecting, acting, and the full range of human feelings, emotions, and inspirations to happen. It is constitutional to human thinking and living. "The possibility of reflection on the self, discovery of the ego, capacity for performing any epoch $\vec{e}$, as Schutz writes, "and the possibility of all communication and of establishing a

\footnotetext{
${ }^{1}$ Husserl, "Fifth Meditation", p. 98.

2 Ibid., p. 107.

${ }^{3}$ Schutz, "The Problem of Transcendental Intersubjectivity in Husserl”, p. 82.
} 
communicative surrounding world as well, are founded on the primal experience of the we-relationship"1.

\section{Heidegger's hermeneutics of intersubjectivity}

This section responds to the third question this article poses: "What can Heidegger's hermeneutics (hermeneutic-phenomenology) of intersubjectivity add to Schutz's interpretation of the phenomenon?" Despite Schutz's commitment to Husserl's transcendental-phenomenological enterprise, one whose psychological orientation and Cartesian language make it remarkable conducive to his sociology, and the absence of mention of Heidegger's hermeneutics in his writings, the apparent openness of Schutz's interpretation of intersubjectivity to Heidegger's rendition of the phenomenon suggests there may be phenomenological returns to be had by exposing the former's thinking of the matter to the hermeneutics of the latter. Heidegger's thinking signifies a single course that unfolds from thinking Da-sein (t/here-being) in relation to Sein (being), the transcendental-horizonal perspective initiated in Being and Time ${ }^{2}$, his first major work, to thinking Seyn (be-ing, Ereignis, enowning) in relation to Da-sein, the being-historical perspective freed in Contributions to Philosophy (From Enowning) ${ }^{3}$, his second major work. Being-historical thinking ("historical mindfulness", geschichtliches Besinnung) signifies the endeavor of "laying out of being as phenomenon in a radical sense"4. It thinks (projects-open) being as be-ing, or enowning, the ownmost (essential, Wesen) sway (be-ing is the ownmost sway) that clears the open space (Grund) wherein beings manifest from hiddenness (Abgrund) or shows their meaning as "staying-away". It discerns be-ing prephilosophically as $\dot{\alpha} \lambda \dot{\eta} \theta \varepsilon ı \alpha$ (truth), the primal self-showing-shelteringwithdrawing (of beings). En-owning (Er-eignis) passively (not causally)

\footnotetext{
${ }^{1}$ Ibid., p. 82.

${ }^{2}$ Martin Heidegger, Being and Time, trans. John Macquarrie and Edward Robinson (New York: Harper \& Row, Publishers, 1962).

${ }^{3}$ Contributions to Philosophy (from Enowning), trans. Parvis Emad and Kenneth Maly (Bloomington: Indiana University Press, 1999).

${ }^{4}$ George Kovacs, "The Idea of Hermeneutics in Heidegger", Existentia 10, no. 1-4 (2000), p. 44; "Becoming Mindful of the History of Be-ing", Heidegger Studies 33 (2017).

5 Parvis Emad and Kenneth Maly, "Translator's Forward", in Contributions to Philosophy (from Enowning) (Bloomington: Indiana University Press, 1999), pp. Xxx-Xxxi.
} 
enables t/here-beings to be (show themselves from themselves as they are in themselves) and pervasively shapes their being (meaning) from within/through their being by unveiling them, leaving them veiled, or showing their meaning as withdrawing from transcendence. It is historical (geschichtliches) in the sense of issuing, unfolding, and proffering ${ }^{1}$ and the free, open, directional "interplay" among human being, beings, and "to-be" ("time-play-space") rather than historiographical, linear, or chronometric (Historie) $)^{2}$.

1. First moment. Heidegger does not write of intersubjectivity per se. The term, "intersubjective" (inter-subjective), resonates with connotations implying a Cartesian individuation of human being incompatible with Heidegger's way of thinking and expanded syntax of transcendence and "to be". The response to the problem of intersubjectivity in Heidegger's hermeneutics ensues from its elucidation of human being as $t / h e r e-b e i n g$ and be-ing as enowning. One of the responses is explicit. Two are implicit. Heidegger gives perhaps his most direct description of intersubjectivity, so to speak, the first moment within his hermeneutics of the phenomenon, in sections 25 through 27 of Being and Time ${ }^{3}$. There he propositionally locates the originary comprehension of the "other" in the "with" structure (meaning) of existence. Being-with (Mitsein) and being-with-others (Mitdasein) are equiprimordial to being-in-the-world (In-der-Welt-sein), Heidegger asserts ${ }^{4}$. They are existentials, sway in transcendence, and, like being-in-the-world, signify factical Da-sein as its disclosedness. The first moment within Heidegger's hermeneutics of intersubjectivity reveals being-with and beingwith-others to be ownmost to the coming-to-pass of human being as beingin-the-world and its appropriation of the "other".

"Being" and "with" are primordial words whose ownmost eludes conceptualization. Their fundamental significance discloses-says primal experiences rather than communicating concepts or abstractions; thinking alienates itself from the meaning of "being" and "with", from the hermeneutical moment of "being-awake of Da-sein for itself", insofar as it abstracts the phenomena. The power of "being" and "with" to disclose-say comes from their phenomenal equivalency to the meanings the words liberate

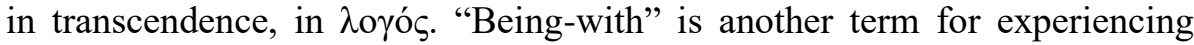

\footnotetext{
${ }^{1}$ Ibid., p. xxiii.

${ }^{2}$ Kovacs, "Becoming Mindful of the History of Be-ing”, pp. 130-131, 139.

${ }^{3}$ Heidegger, Being and Time, pp. 149-168.

${ }^{4}$ Ibid., p. 149.

${ }^{5}$ Kovacs, "The Idea of Hermeneutics in Heidegger", p. 46.
} 


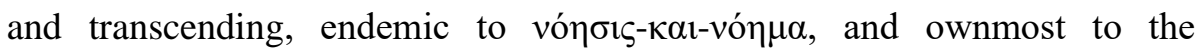
untranslatable, voũc; the hermeneutic-phenomenological rendition of "beingwith" may be one of the more reliable translations of voũs. To-be-with something or someone includes going beyond it/him as a being (غ̇òv) and enduring (coming to pass as) its/his being (غ̇óv) or meaning, as denoted by

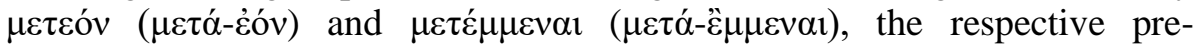
Socratic equivalents to being-with and to-be-with. "With" belongs to being. It is always spoken in conjunction with "is". Being-with does not signify a coupling or correlation of t/here-being to the World. It signifies t/here-being as the World and being-of-t/here.

Being-with-others nucleates from being-with and is included in it. Being-with-others is more than a joining, correspondence, or harmonious synthesis of separate psychophysical entities ("person-Things present-athand") or t/here-beings ${ }^{1}$. It is more profound than the connectivity, affinity, or congruence commonly inferred from "togetherness", "shared", "intersubjectivity", the "We-relationship", or empathy, which is often discerned as an "ontological bridge" between isolated subjects ${ }^{2}$. It denotes a phenomenal continuity and unity among distinct (but not discrete!) t/here-beings. It says the "others" t/here-being encounters, directly or indirectly (referentially), are "like $t$ /here-being; they are characterized by the 'to-be' (sein), by the ' $t /$ here' $(d a)$, and by the "with' (mit)"3. It says t/here-being transcends persons as beings to their being, the ownmost of which is the concern for being (Sorge). Mitdasein is $\mathrm{t} / \mathrm{here}$-being dwelling in the World as other $\mathrm{t} / \mathrm{here}$-beings and among them in "unbroken constancy", to borrow syntactically from Husserl ${ }^{4}$. It signifies the primitive comprehension (endurance) of "others" as the meaning of Da-sein's being: "circumspectively concernful ["circumspective preoccupation"] being-in-the-world" (umsichtig-besorgendes In-der-Weltsein) ${ }^{5}$. Being-t/here-with-others is not standing apart along side ("present-athand-along") "others" ${ }^{\circ}$. It is primordially meeting (coming to pass as, enduring) "others" as being-in-the-world and "being-t/here-too"7. Being-

\footnotetext{
${ }^{1}$ Heidegger, Being and Time, p. 156.

${ }^{2}$ Ibid., p. 162.

${ }^{3}$ George Kovacs, The Question of God in Heidegger's Phenomenology (Evanston: Northwestern Universit Press, 1990), p. 73.

${ }^{4}$ Husserl, The Crisis of European Sciences and Transcendental Phenomenology: An Introduction to Phenomenological Philosophy, p. 144.

${ }^{5}$ Heidegger, Being and Time, p. 154; Kovacs, The Question of God in Heidegger's Phenomenology, p. 73.

${ }^{6}$ Heidegger, Being and Time, p. 154.

${ }^{7}$ Ibid., p. 156.
} 
with-others signifies the "'is-ness' of togetherness (coexistence) in human existence", George Kovacs pointedly writes ${ }^{1}$. The comprehension of the "other" as its own t/here-being comes with (is endemic to) the irruption of transcendence. T/here-being is thrown (geworfen) into the World with a comprehension of the "other" as $\mathrm{t} /$ here-being, being-with, being-with-others, and being-in-the-world. "Others" are not only "present-at-hand nor ready-tohand" 2 . They are factically disclosed "like" the t/here-being that "frees" them in transcendence "in that they are there too, and there with it".

Being-with and being-with-others contain the possibility of language. Discourse, language as such, signifies being-with the things one talks about and being-with-others one talks to. They free language, the ownmost of which includes its thingness and hermeneutic embodiment, to extend the meaning of the phenomenal body into the meaning of the things and "others" spoken of/to ("action at a distance", "corporeal intentionality"), ${ }^{4}$ thus forging the "psychic link which unites us to the world and our fellow men". The matter of the "'mutual tuning-in" Schutz says induces the "simultaneity" of "inner time" ("durée") or "streams of consciousness", notions that resonate with dualistic conceptions of human being, and calls the start-point and basis of the We-relationship ${ }^{6}$ is being-with and being-with-others. The existentials are the foundation of the life-world's intersubjectivity, including, as Husserl asserts, "the I-you-synthesis" and "the more complicated we-synthesis"7. They, and not the social production and distribution of knowledge, are the potentiality of culture and social phenomena. The prospect of a common stock of knowledge and typification also comes from them. "The "withbeing' structure of $t /$ here-being" and the equiprimordiality between $t / h e r e-$ being and t/here-being-with-others are "the foundation of human community and of interpersonal relationships; it is not the product of social or cultural integration". 8

\footnotetext{
${ }^{1}$ Kovacs, The Question of God in Heidegger's Phenomenology, p. 71.

${ }^{2}$ Heidegger, Being and Time, p. 150.

${ }^{3}$ Ibid., p. 154.

${ }^{4}$ Maurice Merleau-Ponty, Signs, trans. Richard C. McCleary (Evanston: Northwestern University Press, 1964), pp. 89, 93.

${ }_{6}^{5}$ Phenomenology of Perception, pp. 137, 180, 185, 196.

${ }^{6}$ Schutz, "Making Music Together: A Study of Social Relationship", pp. 79, 89-90, 92, 95 .

${ }^{7}$ Husserl, The Crisis of European Sciences and Transcendental Phenomenology: An Introduction to Phenomenological Philosophy, p. 172.

${ }^{8}$ Kovacs, The Question of God in Heidegger's Phenomenology, p. 72.
}

\section{9}


The hermeneutic-phenomenological exposition of t/here-being propositionally refutes theses positing transcendental constitution as the source of the originary comprehension of "others". It says the "other" does not ensue from passive identification or passive association emanating from a surmised transcendental ego. It does not, however, gainsay the meaning generating power of passive identification, passive association, or intentional constitution. It says, rather, t/here-being factically is the meaning of the "other". The "other" is not an "alter ego" constituted by the transcendental ego. "Others" are neither "discriminated beforehand and then apprehended; nor are they encountered by a primary act of looking at oneself in such a way that the opposite pole of a distinction first gets ascertained". Indeed, interpreted hermeneutic-phenomenologically, there is no isolated transcendental ego, no "spirit as a synthesis of soul and body", or "self", to constitute "others"2. "Others" does "not mean everyone else but me" or "those over against who the 'I' stands out. They are rather those from whom, or the most part, one does not distinguish oneself" and "those among whom one is too"3; the "with" of being-with and being-with-others includes "among", as indicated by the pre-Socratic $\mu \varepsilon \tau$. . The hermeneutical exposition of $t / h e r e-$ being as being-in-the-world reveals there is no "bare subject without a world" and no "isolated "I" without "others" monad and the World (Objectivity) is not constituted by a plurality of monads. The "self", exhibited hermeneutic-phenomenologically, is the being-of-t/here. It is a "who" that factically includes the meaning of the "other"; the "who' of the everyday Dasein just is not the "I myself"" .

2. Second moment. The hermeneutic-phenomenological exposition of t/here-being as being-with, being-with-others, and being-in-the-world, the self-showing of factical Da-sein by way of unearthing these existentials, yields the second and third moments ("joinings") of Heidegger's rendition of intersubjectivity. The second moment says human being from the outset is intersubjective because the World, paivó $\mu \varepsilon v o v$ (reality as such, or human reality) is a singularity, and we are all t/here indivisibly the manifestation of it. The illumed $D a$ of $t /$ here-being is "a multidimensional, and yet a singular phenomenon of disclosure", Kalary and Schalow observe, and t/here-being is

\footnotetext{
${ }^{1}$ Heidegger, Being and Time, p. 155.

2 Ibid., p. 150.

${ }^{3}$ Ibid., p. 154.

${ }^{4}$ Ibid., p. 150.

${ }^{5}$ Ibid., pp. 149-150.
} 
"clearing" itself. It "stands for the world that is horizonally disclosed". The discernment of World, a totality of manifold $\varphi \alpha \imath$ ó $\mu \varepsilon v \alpha$ rather than a composite of discrete $\varphi \alpha i v o ́ \mu \varepsilon v \alpha$, reveals the "is-ness" of togetherness to be far more profound and expansive than the rendition of intersubjectivity Schutz communicates. So profound and expansive is this "is-ness" that phenomenology commonly stumbles thinking it. "Insofar as ontological difference strengthens the assumption that we can think be-ing within the perspective of beings", Emad writes, it contains "something discording" because "it splits the onefold" of be-ing and beings, a singular totality, he adds, "that must be thought at all cost" if phenomenology is to liberate its meaning and bring it to view ${ }^{2}$. This "something discording" may partly be the result of, as Kovacs remarks about hermeneutics generally, language running "up against its limit in attempting to capture the play and the depth of the World"3.

The first two moments of Heidegger's rendition of intersubjectivity propositionally validate Schutz's decision to commence his hermeneutics from the perspective, subjectivity is intersubjectivity and the life-world of the natural attitude is factically shared. It supports his thesis, intersubjectivity is pragmatic, that is, read hermeneutic-phenomenologically, it is grounded in the being of things, or their thingness (the being of a thing is its thingness!) ${ }^{4}$, thus underscoring his assertion intersubjectivity is inherent to the "wideawakeness" of the everyday person, or the person whose intentional acts are dominated by "eminently practical" interests. They speak to the potentiality of the person to develop (grow, mature, falsify, validate) the understanding of the "other", life, and the common typifications within his stock of knowledge. They descriptively correspond with the rendition of (human) reality delivered by contemporary physics and cybernetics, thus agreeing with Schutz's assertion: "the results of phenomenological research cannot and must not clash with the tested results of the mundane sciences"5. T/herebeings belong to the unity of space and time (space-time); time is not

1 Thomas Kalary and Frank Schalow, "Attunement, Discourse, and the Onefold of Hermeneutic Phenomenology: Recent Heidegger-Literature and a New Translation of His Work in Critical Perspective", Heidegger Studies 27 (2011), pp. 201-202.

2 Parvis Emad, "On the Inception of Being-Historical Thinking and Its Unfolding as Mindfulness", ibid.16 (2000), pp. 57-58.

${ }^{3}$ George Kovacs, "New Horizons in Understanding Heidegger's Thought”, ibid. 22 (2006), p. 228.

${ }^{4}$ Martin Heidegger, "The Origin of the Work of Art", in Poetry, Language, Thought, ed. Albert Hofstadter (New York: Perennial Classics, 2001), pp. 25, 31.

${ }^{5}$ Schutz, "Some Leading Concepts of Phenomenology", p. 95.

21

Bull. anal. phén. XIV 7 (2018)

https://popups.uliege.be/1782-2041/ @ 2018 ULiège BAP 


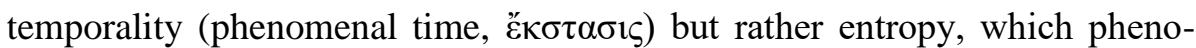
menology, in its own way, per Father Richardson, renders as $\dot{\alpha} \rho \chi \eta \dot{\eta} \chi\left\llcorner v \dot{\eta} \sigma \varepsilon \omega \varsigma^{1}\right.$. T/here-beings are not separated by space-time. Physical space, time, and beings constitute a physical unity. Phenomenal space, time, and beings constitute a phenomenal unity. Space, time, and beings, in either perspective, are not disconnected variables. They constitute a unified totality.

The hermeneutic-phenomenology of intersubjectivity, as witnessed in its first two moments, deepens the understanding of intersubjectivity Schutz posits. They descriptively reveal, beyond the stand-alone assertion the lifeworld is fundamentally shared, the ownmost of intersubjectivity is not learned. Its originary genesis is not located in the social production or social distribution of knowledge. Its nucleation is not found in the typification or passive association. It is found in the existentials being-with, being-withothers, and being-in-the-world. The potentiality (power and possibility,

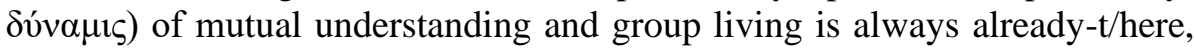
shining forth from the ownmost of factical Da-sein. The exhibition of human existence as the being-of-t/here (being-in-the-world, the onefold, paıvó $\mu \varepsilon v 0 v$, World) and the discernment of its ontological structure as beingwith and being-with-others (the first moment within Heidegger's hermeneutics of intersubjectivity) expose the World as a singularity (the second moment). It says, within the context of the principle of "man-World relatedness", namely, "no World without $\mathrm{t} /$ here-being" and "no $\mathrm{t} / \mathrm{here-being}$ without World", t/here-beings uniquely manifest as one paivó $\mu \varepsilon v o v$ and not separate $\varphi \alpha \imath v o ́ \mu \varepsilon v \alpha$. It says each and every $\mathrm{t} /$ here-being is the being-of-t/here, there is only one $t / h e r e$, notwithstanding the different openings (dimensions) available to the unique, individual t/here-being contingent on its spatiotemporal situation and the general and individual power and proclivity of $\lambda$ oyó $\zeta$, and being is a singularity; each t/here-being is not freed to be by a different "is", although they may comprehend its meaning differently, thus coming closer to or alienating themselves from it (and $\dot{\alpha} \lambda \dot{\eta} \theta \varepsilon 1 \alpha$ ). T/herebeing may harbor and shepherd the meaning of "is", but it does not own being, keeping in mind, as hermeneutic phenomenology asserts, that be-ing is not a being, beings, including t/here-being, rely on be-ing to be, and be-ing cannot be thought as a being ${ }^{3}$. T/here-beings are the "is-ness" of their togetherness. They are the being of beings-in-the-whole (das Seiende im

\footnotetext{
${ }^{1}$ William J. Richardson, S.J., Heidegger: Through Phenomenology to Thought, 2nd ed. (The Hague: Martinus Nijhoff, 1967), p. 313.

${ }^{2}$ Kovacs, The Question of God in Heidegger's Phenomenology, p. 62.

${ }^{3}$ Heidegger, Contributions to Philosophy (from Enowning), pp. 22, 52, 183.
} 
Ganzen); "the truth of be-ing is nothing less than the essential sway of truth grasped and grounded as the sheltering that lights up, the happening of $D a$ sein $^{1}$. They are equally original (gleichursprünglich) being-in-the-world. They, together, liberated by be-ing to be, are the World.

3. Third moment. The third moment within Heidegger's hermeneutics of intersubjectivity comes with its elucidation of the relation among t/herebeing, language, and be-ing. Heidegger's extensive treatment of language, his phenomenological investigation and disclosure of language as a profoundly ontological phenomenon, one he surmises is enowned by be-ing and says is equally primordial with human Da-sein, delivers four theses that respond in their own way to the question implied by Merleau-Ponty's observation that the meaning of language "is at first concealed by the relations belonging to the domain of being". ${ }^{2}$ They also, again, in their own way, respond to Merleau-Ponty's question concerning the liberation of meaning in/through language, which is, "How did the available meanings themselves come to be constituted?" 3 The four theses tabled here are: "human being is language", "we-human beings-are a conversation", "language is the house of being", and be-ing enowns language and is "underway" in language ${ }^{7}$. Language frees being, which is always, no matter how it is thought, the being of something, and the meaning of "to be" (enowning) through words. It sways in transcendence. It discloses-says phenomena by delivering t/here-being to the truth of beings, conceals phenomena, for example, through chatter, "the forced rattling of concepts and empty words", witnessed in the common struggle to discern basic human phenomena (e.g., love, freedom, values, ultimate meaning, the question of God). Language is enowned by be-ing. Heidegger's hermeneutics surmises language is a way,

\footnotetext{
${ }^{1}$ Ibid., p. 133.

${ }^{2}$ Merleau-Ponty, Phenomenology of Perception, p. 174.

${ }^{3}$ Ibid, p. 186.

${ }^{4}$ George Kovacs, "Heidegger's Insight into the History of Language", Heidegger Studies 29 (2013), p. 129.

5 Martin Heidegger, "Hölderin and the Essence of Poetry", in Elucidations of Hölderlin's Poetry, ed. Keith Hoeller (Amherst: Humanity Books, 2000), pp. 55-56.

6 "The Nature of Language", in On the Way to Language, ed. Peter D. Hertz (San Francisco: HarperCollins Publisherss, 1982), p. 63.

7 "The Way to Language", in Basic Writings, ed. David Farrell Krell (San Francisco: HarperCollins, 1993); "The Nature of Language"; "Hölderin and the Essence of Poetry".

${ }^{8}$ Contributions to Philosophy (from Enowning), p. 16.
} 
perhaps one of the most principal ways given the relation between language and World-manifestation, be-ing en-owns (er-eignet) transcendence. Language contains the fundamental moments of be-ing. It is its principal moments. Language frees phenomena from their concealment, shelters them, or illumes them as staying-away. It liberates the manifestation of beings as beings-in-the-whole, the onefold, a singularity signifying t/here-beings as clearing-concealing-withdrawing itself, and concretely manifests the "isness" of togetherness; it is the manifestation of "is-ness!"- "Where there is language, is there world"1. T/here-beings bound by the same language more or less abide the same dimensions of the World. They do not constitute or live different Worlds. They stand in the midst of the same openness.

Through language t/here-being bears "witness" to what it is"; "we are within language, at home in language, prior to everything else" . Language radically reveals, so much so that its sway eludes disclosure, the meaning of t/here-being as to-be-with and to-be-with-others. It comes from these existentials and frees their issuance and unfurling in the World. It graces t/here-being with the meaning of "is" and opens the way for the coming to pass beings-in-the-whole. Language frees t/here-beings to be the World, the being-of-t/here, and the "other". It frees the "is-ness" of togetherness to be, thus allowing "a taking up of 'others' thought through speech" and thinking "according to 'others"', as Merleau-Ponty writes. ${ }^{4}$ If human being did not posses language, the World and everything it encompasses would be devoid of being and meaning: "Where word breaks off no thing may be" (an allusion to Goethe) and without language "the whole of things, the 'world,' would sink into obscurity"5. Beings would show themselves but they would not show themselves from themselves as they are, which means, within the context of the phenomenological problematic, they would have neither being nor meaning (being includes meaning). A world without language is a world without truth. There is no being-in-the-world, beings-in-the-whole, or World without language. The situation of a person devoid of language would be dominated (engulfed from within) by shelteredness, or $\chi \alpha$ ós: "the gaping out of which the open opens itself" and being and meaning, hence the World, manifest ${ }^{6}$ - also discerned as, Abgrund (abground), "the staying-away of

\footnotetext{
1 "Hölderin and the Essence of Poetry", p. 56.

${ }^{2}$ Ibid., pp. 54-56.

3 “The Way to Language", p. 398.

${ }^{4}$ Merleau-Ponty, Phenomenology of Perception, p. 179. Slightly modified.

${ }^{5}$ Heidegger, "The Nature of Language", pp. 72-73.

6 "Hölderin and the Essence of Poetry", p. 85.
} 
ground that is part and parcel of Grund [ground]"1. This person would be a thing among things and the being and meaning of things would remain hidden from him.

Heidegger's hermeneutics radically extends Schutz's theses about language and its relation to intersubjectivity. It does not oppose his interpretation of language. It expands and deepens it. It reveals the ownmost of language to be profoundly ontological. It augments Schutz's interpretation of language by showing the phenomenon to be more than, as Schutz posits: a system of signs and indicators and a storehouse of social knowledge, "the typifying medium par excellence by which socially derived knowledge is transmitted", a "treasure house of ready made pre-constituted types and characteristics", the means of achieving a reciprocity of perspectives ${ }^{2}$, a vehicle for communication ${ }^{3}$, a system of "named things and events", a means to "come to terms" with a "given situation" to realize oneself $4^{4}$, or even, as he writes regarding the performance of music, a way of sharing "in vivid present the other's stream of consciousness in immediacy"s. These assertions, less so the one about music, which leans toward a hermeneutic-phenomenological interpretation of language though still ignores the question of being (e.g., "immediacy", "vivid present"), reflect a technicity-based view of languagea way of seeing language, the World, human being, and "to be" correlated with a "forgottenness of being" that alienates thinking from a fuller disclosure of human reality, of patvó $\mu \varepsilon v o v^{6}$. They obscure the intimate relation hermeneutic-phenomenology exhibits among language, t/here-being, and being, as conveyed by the observations: "human being is language" and "we are a conversation". The hermeneutic-phenomenology of language reveals being-in-the-world manifests in/with/through language. It opens Schutz's sociology to the "mystery" of language, including the relation surmised

${ }^{1}$ Kenneth Maly, “Translating Heidegger's Works into English: The History and the Possibility", Heidegger Studies 16 (2000), p. 136.

${ }^{2}$ Schutz, "Common-Sense and Scientific Interpretation of Human Action", p. 10.

3 "Symbol, Reality and Society", in Symbols and Society: Fourteenth Symposium on Science, Philosophy, and Religion, ed. Lyman Bryson, et al. (New York: Harper and Brothers, 1955), p. 165.

4 "Language, Language Disturbances, and the Texture of Consciousness", pp. 372, 392.

5 "Making Music Together: A Study of Social Relationship", p. 95.

${ }^{6}$ Heidegger, Contributions to Philosophy (from Enowning), 92; Mindfulness, trans. Parvis Emad and Thomas Kalary (London: Continuum International Publishing Group, 2006), pp. 152-153; Kovacs, "Heidegger's Insight into the History of Language", pp. 123-124. 
between language and be-ing, and the primordial equivalency language shares with $\mathrm{t} / \mathrm{h}$ ere-being, the "is-ness" of togetherness (being-with and beingwith-others), and being-in-the-world. It says language issues and shapes the World. The meaning and structure of the life-world of the natural attitude, a phenomenon Schutz correctly says is factically intersubjective, is language, according to Heidegger's analysis.

\section{Concluding observations}

A hermeneutic-phenomenological reading of Schutz's interpretation of intersubjectivity connotes a shortcoming in his hermeneutics of the world of daily. It suggests his sociology may be selling itself short by restricting its analysis to the life-world of the natural attitude. It implies Schutz's sociology may be restraining its disclosing-saying power and empirical development by failing to include, or at a minimum address, theses wrested from the hermeneutic-phenomenological investigation of t/here-being and be-ing. Schutz's failure to address the more profound dimensions of the relation between language and intersubjectivity appear to be, at least as assessed here, symptomatic of his sociology as a whole. "Without grasping the "equal primordial' of discourse properly, one can never have an appropriate understanding of the very phenomenon of 'disclosure' itself", Kalary and Schalow assert ${ }^{1}$. It exposes his sociology to "ontological blackout" and threatens to quash its ability to exhibit the human situation. It abates the disclosingsaying power of the general theses his understanding of intersubjectivity comprises, especially, "subjectivity is intersubjectivity" and "intersubjectivity is language". It makes his sociology susceptible to Cartesian interpretations of the world of daily life, particularly among persons who sidestep the sweat-inducing work of phenomenology, and inferences sourcing intersubjectivity to the social construction of reality.

These observations do not recommend supplanting Schutz's theses about intersubjectivity with hermeneutic-phenomenological ones. They also do not disparage Schutz's phenomenological contributions to sociology. Schutz gifted sociology with a new, more open way of seeing and interpreting the social dimensions of the everyday life of the everyday person. Berger and Luckmann, for example, credit their "redefinition" of the

${ }^{1}$ Thomas Kalary and Frank Schalow, "Attunement, Discourse, and the Onefold of Hermeneutic Phenomenology: Recent Heidegger-Literature and a New Translation of His Work in Critical Perspective", Heidegger Studies 27 (2011), p. 205.

26

Bull. anal. phén. XIV 7 (2018)

https://popups.uliege.be/1782-2041/ @ 2018 ULiège BAP 
"sociology of knowledge", the one they communicate in their landmark work, The Social Construction of Reality, to the thinking of Schutz and his phenomenological exhibition of "the structure of the commonsense world of daily life". The methodological vigor of Schutz's sociology, notwithstanding its Cartesian language, comes in no small measure from its phenomenological insights and specificity. His hermeneutics provides social scientists a reliable way to deconstruct social phenomena consistently and methodically. Its phenomenological basis not only includes the possibility of growing and enhancing its interpretation of the world of daily life, it demands it; phenomenology is a possibility, one "that never ends and always begins anew". These observations suggest hermeneutic-phenomenology as a way to fulfill that charge and, within the context of this article, deliver a more expansive understanding of intersubjectivity. They proffer the hermeneutics of t/here-being and be-ing, inceptually thinking them, as a "to-be-thought" within Schutz's sociology. They suggest Schutz's sociology, generally speaking, might profit from the assimilation of hermeneutic-phenomenological considerations, both transcendental-horizonal and being-historical. They say hermeneutic-phenomenology contains the potentiality of guarding Schutz's sociology, when distanced from its phenomenological basis, against inferences attributing the foundational source of intersubjectivity to the social production and distribution of knowledge. They recommend his sociology propositionally include or at least consider, perhaps, the hermeneuticphenomenological exhibition of intersubjectivity to yield a more comprehensive and robust understanding of the world of everyday life.

\section{References}

Berger, Peter L., and Thomas Luckmann. The Social Construction of Reality: A Treatise in the Sociology of Knowledge. New York: Doubleday, 1967.

Carr, David. "Introduction". Translated by David Carr. In The Crisis of European Sciences and Transcendental Phenomenology: An Introduction to Phenomenological Philosophy, xv-xliii. Evanston: Northwestern University Press, 1970.

Emad, Parvis. "On the Inception of Being-Historical Thinking and Its Unfolding as Mindfulness". Heidegger Studies 16 (2000): 55-71.

${ }^{1}$ Peter L. Berger and Thomas Luckmann, The Social Construction of Reality: A Treatise in the Sociology of Knowledge (New York: Doubleday, 1967), pp. 16-17.

27 
Emad, Parvis, and Kenneth Maly. "Translator's Forward". In Contributions to Philosophy (from Enowning), xv-xliv. Bloomington: Indiana University Press, 1999.

Gurwitsch, Aron. "Introduction". In Collected Papers III: Studies in Phenomenological Philosophy, edited by I. Schutz, XI-XXXI. The Hague: Martinus Nijhoff, 1966.

Heidegger, Martin. Being and Time. Translated by John Macquarrie and Edward Robinson. New York: Harper \& Row, Publishers, 1962.

-. Contributions to Philosophy (from Enowning). Translated by Parvis Emad and Kenneth Maly. Bloomington: Indiana University Press, 1999.

-. "Hölderin and the Essence of Poetry". Translated by Keith Hoeller. In Elucidations of Hölderlin's Poetry, edited by Keith Hoeller, 51-65. Amherst: Humanity Books, 2000.

- Mindfulness. Translated by Parvis Emad and Thomas Kalary. London: Continuum International Publishing Group, 2006.

-. "The Nature of Language". Translated by Peter D. Hertz. In On the Way to Language, edited by Peter D. Hertz. San Francisco: HarperCollins Publisherss, 1982.

-. "The Origin of the Work of Art". Translated by Albert Hofstadter. In Poetry, Language, Thought, edited by Albert Hofstadter, 15-86. New York: Perennial Classics, 2001.

-. "The Way to Language". Translated by David Farrell Krell. In Basic Writings, edited by David Farrell Krell, 397-426. San Francisco: HarperCollins, 1993.

Husserl, Edmund. The Crisis of European Sciences and Transcendental Phenomenology: An Introduction to Phenomenological Philosophy. Translated by David Carr. Evanston: Northwestern University Press, 1970.

—. "Fifth Meditation". Translated by Dorion Cairns. In Cartesian Mediations: An Introduction to Phenomenology, 89-157. Boston: Kluwer Academic Publishers, 1999.

Kalary, Thomas, and Frank Schalow. "Attunement, Discourse, and the Onefold of Hermeneutic Phenomenology: Recent Heidegger-Literature and a New Translation of His Work in Critical Perspective". Heidegger Studies 27 (2011): 199-210.

Kovacs, George. "Becoming Mindful of the History of Be-ing". Heidegger Studies 33 (2017): 129-43.

-. "Heidegger's Insight into the History of Language". Heidegger Studies 29 (2013): 121-32.

—. "The Idea of Hermeneutics in Heidegger". Existentia 10, no. 1-4 (2000): 41-50.

-. "New Horizons in Understanding Heidegger's Thought". Heidegger Studies 22 (2006): 217-32.

-. The Question of God in Heidegger's Phenomenology. Evanston: Northwestern Universit Press, 1990. 
Luckmann, Thomas. "Preface". In The Structures of the Life-World, xvii-xxvi. Translated by Richard M. Zaner and Jr. H. Tristram Engelhardt. Vol. 1, Evanston: Northwestern University Press, 1973.

Maly, Kenneth. “Translating Heidegger's Works into English: The History and the Possibility". Heidegger Studies 16 (2000): 115-38.

Merleau-Ponty, Maurice. Phenomenology of Perception. Translated by Colin Smith. London: Routledge \& Kegan Paul, 1962.

-. Signs. Translated by Richard C. McCleary. Evanston: Northwestern University Press, 1964.

Richardson, S.J., William J. Heidegger: Through Phenomenology to Thought. 2nd ed. The Hague: Martinus Nijhoff, 1967.

Schutz, Alfred. "Choosing Among Projects of Action". Philosophy and Phenomenological Research 12, no. 2 (December 1951): 161-84.

- Collected Papers I: The Problem of Social Reality. Edited by I. Schutz. The Hague: Martinus Nijhoff, 1972.

- Collected Papers II: Studies in Social Theory. The Hague: Martinus Nijhoff, 1976.

-. Collected Papers III: Studies in Phenomenological Philosophy. The Hague: Martinus Nijhoff, 1966.

-. "Common-Sense and Scientific Interpretation of Human Action". Philosophy and Phenomenological Research 14, no. 1 (September 1953): 1-38.

-. "Discussion: Edmund Husserl's Ideas, Volume II". Philosophy and Phenomenological Research 13, no. 3 (March 1953): 394-413.

-. "Language, Language Disturbances, and the Texture of Consciousness". Social Research 17, no. 3 (September 1950): 365-94.

—. "Making Music Together: A Study in Social Relationship". Social Research 18, no. 1 (March 1951): 76-97.

- "Max Scheler's Epistemology and Ethics, I". The Review of Metaphysics 11, no. 2 (December 1957): 304-14.

-. "Max Scheler's Epistemology and Ethics: II". The Review of Metaphysics 11, no. 3 (December 1958): 486-501.

-. “On Multiple Realities". Philosophy and Phenomenological Research 5, no. 4 (June 1945): 533-76.

- The Phenomenology of the Social World. Translated by George Walsh and Frederick Lehnert. Evanston: Northwest University Press, 1967.

—. "The Problem of Rationality in the Social World". Economica 10, no. 38 (May 1943): 130-49.

-. "The Problem of Transcendental Intersubjectivity in Husserl". In Collected Papers III: Studies in Phenomenological Philosophy, edited by I. Schutz, 51-83. The Hague: Martinus Nijhoff, 1966.

- Reflections on the Problem of Relevance. New Haven: Yale University Press, 1970. 
—. "Scheler's Criticism of Kant's Philosophy". In Collected Papers III: Studies in Phenomenological Philosophy, edited by I. Schutz, 155-63. The Hague: Martinus Nijhoff, 1966.

- "Scheler's Theory of Intersubjectivity and the General Thesis of the Alter Ego". Philosophy and Phenomenological Research 2, no. 3 (1942): 323-47.

—. "Some Leading Concepts of Phenomenology". Social Research 12, no. 1 (1944): 77-97.

-. "The Stranger: An Essay in Social Psychology". American Journal of Sociology 49, no. 6 (May 1944): 499-507.

—. "Symbol, Reality and Society". In Symbols and Society: Fourteenth Symposium on Science, Philosophy, and Religion, edited by Lyman Bryson, Louis Finkelstein, Hudson Hoagland and R.M. MacIver, 135-203. New York: Harper and Brothers, 1955.

—. "Type and Eidos in Husserl's Late Philosophy". In Collected Papers III: Studies in Phenomenological Philosophy, edited by I. Schutz, 92-115. The Hague: Martinus Nijhoff, 1966.

-. "The Well-Informed Citizen: An Essay on the Social Distribution of Knowledge". Social Research 13, no. 4 (December 1946): 463-478.

Schutz, Alfred, and Thomas Luckmann. The Structures of the Life-World. Translated by Richard M. Zaner and Jr. H. Tristram Engelhardt. Vol. 1, Evanston: Northwestern University Press, 1973.

- The Structures of the Life-World. Translated by Richard M. Zaner and Jr. H. Tristram Engelhardt. Vol. 2, Evanston: Northwestern University Press, 1973.

Wagner, Helmut R. "Introduction". In On Phenomenology and Social Relations: Selected Writings, edited by Helmut R. Wagner, 1-50. Chicago: University of Chicago Press, 1970.

Walsh, George. "Introduction”. Translated by George Walsh and Frederick Lehnert. In The Phenomenology of the Social World, xv-xxix. Evanston: Northwest University Press, 1967. 